\title{
PERBEDAAN PERSEPSI CITA RASA, ASUPAN ENERGI, DAN ZAT GIZI MAKRO SEBELUM DAN SESUDAH MODIFIKASI LAUK NABATI DI PANTI ASUHAN AL-IKHWANIYAH TANGERANG SELATAN
}

\section{Difference in flavor perception, energy intake, and macronutrient intake before and after modification of plant-based protein at Al-Ikhwaniyah orphanage in South Tangerang}

\author{
Dini Puspita Sari1)*, Irfanny Z Anwar2), Mira Sofyaningsih'1) \\ 1) Program Studi Gizi, Fakultas Ilmu-Ilmu Kesehatan, Universitas Muhammadiyah Prof. DR. Hamka, Jakarta, \\ Indonesia \\ 2) Politeknik Kesehatan Kemenkes Jakarta II \\ *E-mail korespondensi: dinidini.puspitasari@gmail.com
}

\begin{abstract}
ABSTRAK
Protein sebagai zat pembangun tubuh merupakan bahan pembentuk jaringan baru. Konsumsi lauk nabati di Panti Asuhan Al-Ikhwaniyah Tangerang Selatan sangat rendah dikarenakan banyak lauk nabati yang tidak dikonsumsi atau terjadi sisa pada lauk nabati. Asupan zat gizi pada anak yang tinggal di asrama lebih rendah dibandingkan dengan anak yang tidak tinggal di asrama. Faktor internal penyebabnya yaitu konsumsi makanan dan nafsu makan serta faktor eksternal seperti cita rasa makanan, penampilan makanan, variasi menu, cara penyajian, kebersihan alat makan, dan pengaturan waktu makan. Tujuan penelitian ini untuk melihat perbedaan persepsi cita rasa dan daya terima makanan lauk nabati sebelum dan sesudah dimodifikasi. Subjek penelitian sebanyak 34 orang anak Panti Asuhan Al-Ikhwaniyah yang memenuhi kriteria inklusi. Hasil penelitian adalah terdapat perbedaan persepsi cita rasa tempe dan tahu dengan aspek rasa, aspek aroma, dan aspek warna. Terdapat perbedaan asupan energi, asupan karbohidrat, asupan protein, dan asupan lemak. Memodifikasi lauk nabati secara signifikan dapat menaikkan kesukaan dan asupan zat gizi pada anak-anak di Panti Asuhan Al-Ikhwaniyah.
\end{abstract}

Kata Kunci: Daya Terima Makanan, Modifikasi Lauk Nabati, Persepsi Cita Rasa

\section{ABSTRACT}

Protein is as a body building substance and as a new tissue forming material. The consumption of plant-based protein at Al-Ikhwaniyah Orphanage in South Tangerang was very low because many plant-based proteins were not consumed or leftover food on many plant-based protein. Nutritional intake in children living in a dormitory was lower compared to of the children not living in a dormitory. Internal factors were food consumption and appetite, while external factors were food taste, food appearance, menu variations, food presentation, cleanliness cutlery, and eating time settings. This study aimed to see differences in perceptions of taste and acceptability of plant-based protein before and after being modified. The research subjects were 34 children of Al-Ikhwaniyah Orphanage who met the inclusion criteria. The results of the study were that there were differences in the perception of plant-based protein and tofu taste, aroma, and color aspect. There were differences in energy intake, carbohydrate intake, protein intake and fat intake. The modification of plant-based 
protein can significantly increase the preference and nutrient intake of children at Al-Ikhwaniyah Orphanage.

Keywords: Food Acceptability, Modification of plant-based protein, Taste Perception

\section{PENDAHULUAN}

Pemerintah telah membangun beberapa fasilitas yang berguna untuk membentuk perkembangan anak-anak yang terlantar, yaitu Panti Asuhan. Anak-anak merupakan salah satu kelompok yang rawan mengalami gizi kurang, di antara penyebabnya ialah tingkat ekonomi yang rendah dan asupan makanan yang kurang seimbang (Anzarkusuma, et al., 2014). Makanan dikatakan bergizi jika mengandung zat makanan yang cukup dalam jumlah dan kualitas yang sesuai dengan kebutuhan tubuh. Makanan yang kita konsumsi setiap hari dapat dibagi dalam beberapa golongan, yaitu protein, lemak, karbohidrat, vitamin, mineral, air, dan serat. Sumber energi dalam bahan makanan dapat diperoleh dari zat gizi makro yaitu karbohidrat, lemak, dan protein (Irianto dan Waluyo, 2010).

Pola konsumsi makanan memengaruhi status gizi. Pola konsumsi makanan ditentukan oleh kualitas dan kuantitas hidangan. Jika susunan hidangannya memenuhi kebutuhan tubuh, baik dari kualitas maupun kuantitasnya, maka tubuh akan mempunyai status gizi yang baik (Khusniyati, et al., 2016).

Berdasarkan penelitian Amelia dkk. di Pondok Pesantren Hidayatullah Makasar, 87 subjek memiliki asupan energi kurang (87\%) dan 13 subjek asupan energinya cukup (13\%); untuk asupan protein, 34 subjek asupannya kurang (34\%) dan asupan cukup sebanyak 66 subjek (66\%); untuk asupan lemak kurang sebanyak 10 subjek (10\%) dan asupan cukup berjumlah 90 subjek (90\%). Konsumsi protein berpengaruh terhadap status gizi anak. Anak membutuhkan protein yang cukup tinggi untuk menunjang proses pertumbuhannya (Pahlevi, 2012).

Daya terima makanan dapat dipengaruhi oleh beberapa faktor, yaitu faktor eksternal dan faktor internal. Faktor internal yaitu pola konsumsi makan yang memengaruhi nafsu makan dan faktor eksternal yaitu cita rasa makanan, penampilan makanan, variasi menu, cara penyajian, kebersihan alat makan, dan pengaturan waktu makan. Aroma dan rasa dari makanan yang disajikan dapat meningkatkan selera makan anak dan tekstur makanan memengaruhi dalam mengonsumsi hidangan.

Modifikasi resep adalah suatu kegiatan untuk meningkatkan menu sehingga lebih berkualitas dalam hal rasa, warna, aroma, tekstur, dan nilai gizi. Selain itu, juga merupakan cara untuk menambah keanekaragaman menu pada suatu institusi. Modifikasi resep perlu dilakukan agar makanan yang disajikan kepada konsumen menjadi menarik sehingga akan meningkatkan selera makan serta meminimalisasi rasa kejenuhan dan sisa 
porsi makanan pada konsumen (Azza, et al., 2016).

Makanan lauk nabati di Panti Asuhan Al-Ikhwaniyah Tangerang Selatan bersisa banyak disebabkan rasa dari lauk nabati yang tidak enak. Oleh sebab itu, perlu dilakukan modifikasi

\section{METODE}

Jenis penelitian yang digunakan adalah penelitian kualitatif dengan desain penelitian eksperimental untuk meneliti pengaruh perlakuan (treatment) pada persepsi cita rasa lauk nabati dan memodifikasi lauk nabati serta melihat perbedaan persepsi cita rasa dan asupan zat gizi di Panti Asuhan Al-Ikhwaniyah Tangerang Selatan, pada bulan Juli tahun 2018. Populasi adalah seluruh anak di Panti Asuhan Al-Ikhwaniyah. Sampel adalah bagian dari populasi yang diambil secara purposive sampling dengan kriteria subjek berusia 13-18 tahun, tinggal di Panti Asuhan AlIkhwaniyah, makan siang dan makan malam di Panti Asuhan Al-Ikhwaniyah, tidak dalam keadaan sakit, bersedia mengikuti penelitian, dan didapatkan sejumlah 34 anak. Analisis data yang digunakan adalah data kategorik (presepsi cita rasa) dan data numerik (hasil perhitungan asupan zat gizi). Uji statistik yang digunakan untuk menganalisis data adalah uji Wilcoxon.

\section{HASIL}

Persepsi Cita Rasa Tempe dan Tahu Sebelum Dimodifikasi

Persepsi cita rasa lauk nabati sebelum dimodifikasi menunjukkan bahwa masih terdapat subjek yang tidak pada hidangan lauk nabati yang dapat diterima oleh subjek. Dengan demikian diharapkan tidak terjadi sisa yang banyak pada makanan lauk nabati dan asupan gizi anak-anak di Panti Asuhan Al-Ikhwaniyah dapat meningkat.

menyukai hidangan lauk nabati yang disajikan oleh pihak panti yaitu menu tempe balado dan tahu goreng seperti yang disajikan pada Tabel 1. Pada hidangan lauk nabati tempe balado sebelum dimodifikasi menunjukkan bahwa $41,2 \%$ subjek menyatakan rasa tidak enak, $47,1 \%$ subjek menyatakan aroma tidak harum, 32,4\% subjek menyatakan tekstur tidak sesuai, 20,6\% subjek menyatakan bentuk tidak menarik, dan 29,4\% menyatakan warna tidak menarik.

Pada hidangan lauk nabati tahu sebelum dimodifikasi yaitu tahu goreng didapatkan sebanyak $58,8 \%$ subjek menyatakan rasa tidak enak, 73,5\% subjek menyatakan aroma tidak harum, $17,6 \%$ subjek menyatakan tekstur tidak sesuai, $17,6 \%$ subjek menyatakan bentuk tidak sesuai, dan $50 \%$ subjek menyatakan warna tidak menarik.

\section{Persepsi Cita Rasa Lauk Nabati Tempe dan Tahu Sesudah Dimodifikasi}

Persepsi cita rasa lauk nabati sesudah dimodifikasi menunjukkan bahwa terdapat kenaikan persentase persepsi cita rasa yang cenderung menyukai hidangan lauk nabati yang dimodifikasi yaitu tumis tempe cabai hijau dan tahu goreng isi seperti yang diperlihatkan pada Tabel 2. Untuk 
hidangan lauk nabati tempe yang dimodifikasi menjadi tumis tempe cabai hijau, sebanyak $100 \%$ subjek menyatakan rasa enak, 97,1\% subjek menyatakan aroma harum, 82,4\% menyatakan tekstur sesuai, 94,1\% subjek menyatakan bentuk sesuai, dan 100\% menyatakan warna menarik. Pada hidangan tahu yang sudah dimodifikasi menjadi tahu goreng isi, $100 \%$ subjek menyatakan rasa enak, 100\% menyatakan aroma harum, 88,2\% menyatakan tekstur sesuai, 94,1\% subjek menyatakan bentuk sesuai, dan 94,1\% subjek menyatakan warna menarik.

\section{Perbedaan Persepsi Cita Rasa Lauk Nabati Sebelum dan Sesudah Dimodifikasi}

Bentuk makanan yang sajikan akan menambah daya tarik dari makanan tersebut. Terdapat perbedaan signifikan pada aspek rasa, aroma, warna sebelum dan sesudah dimodifikasi yang menunjukkan bahwa adanya peningkatan kesukaan pada hidangan lauk nabati tempe dan tahu sesudah dimodifikasi.

\section{Asupan Energi dan Gizi Makro Sebelum dan Sesudah Dimodifikasi}

Asupan energi dan zat gizi makro sebelum dilakukan modifikasi yaitu energi 1113,4 kkal, karbohidrat 123,8 g, protein 33,6 g, dan lemak 54,1 g. Ratarata asupan energi dan zat gizi setelah dimodifikasi didapatkan energi 1469,6 kkal, karbohidrat 189,4 g, protein 41,1 g, dan lemak 63,7 g. Asupan energi dan semua zat gizi makro subjek mengalami peningkatan setelah dilakukan modifikasi terhadap lauk nabati tempe dan tahu. Terdapat perbedaan yang signifikan terhadap asupan energi, karbohidrat, protein, dan lemak sebelum dan sesudah dilakukan modifikasi lauk nabati (Tabel 4).

Tabel 1.

Persepsi cita rasa lauk nabati sebelum dimodifikasi

\begin{tabular}{lcclrc}
\hline \multicolumn{1}{c}{ Tempe Balado } & $\mathbf{n}$ & $\mathbf{0}$ & Tahu Goreng & $\mathbf{n}$ & $\%$ \\
\hline Rasa & & & Rasa & & \\
Tidak Enak & 14 & $41,2 \%$ & Tidak Enak & 20 & $58,8 \%$ \\
Enak & 20 & $58,8 \%$ & Enak & 14 & $41,2 \%$ \\
Aroma & & & Aroma & & \\
Tidak Harum & 16 & $47,1 \%$ & Tidak Harum & 25 & $73,5 \%$ \\
Harum & 18 & $52,9 \%$ & Harum & 9 & $26,5 \%$ \\
Tekstur & & & Tekstur & & \\
Tidak Sesuai & 11 & $32,4 \%$ & Tidak Sesuai & 6 & $17,6 \%$ \\
Sesuai & 23 & $67,6 \%$ & Sesuai & 28 & $82,4 \%$ \\
Bentuk & 7 & $20,6 \%$ & Tidak Menarik & 6 & $17,6 \%$ \\
Tidak Menarik & 27 & $79,4 \%$ & Menarik & 28 & $82,4 \%$ \\
Menarik & & & Warna & & \\
Warna & 10 & $29,4 \%$ & Tidak Menarik & 17 & $50,0 \%$ \\
Tidak Menarik & 24 & $70,6 \%$ & Menarik & 17 & $50,0 \%$ \\
Menarik & & & & & \\
& & & & & \\
\end{tabular}


Tabel 2.

Persepsi subjek terhadap cita rasa lauk nabati sesudah dimodifikasi

\begin{tabular}{lrrlrr}
\hline \begin{tabular}{l} 
Tumis Tempe Cabai \\
\multicolumn{1}{c}{ Hijau }
\end{tabular} & $\mathbf{n}$ & $\mathbf{0}$ & \multicolumn{1}{c}{ Tahu } \\
Goreng Isi & $\mathbf{n}$ & \% \\
\hline Rasa & & & Rasa & & \\
Tidak Enak & 0 & $0 \%$ & Tidak Enak & 0 & $0 \%$ \\
$\begin{array}{l}\text { Enak } \\
\text { Aroma }\end{array}$ & 34 & $100 \%$ & Enak & 34 & $100 \%$ \\
Tidak Harum & 1 & $2,9 \%$ & Tidak Harum & 0 & $0 \%$ \\
Harum & 33 & $97,1 \%$ & Harum & 34 & $100 \%$ \\
Tekstur & & & Tekstur & & \\
$\begin{array}{l}\text { Tidak Sesuai } \\
\text { Sesuai }\end{array}$ & 6 & $17,6 \%$ & Tidak Sesuai & 4 & $11,8 \%$ \\
Bentuk & 28 & $82,4 \%$ & Sesuai & 30 & $88,2 \%$ \\
Tidak Menarik & 2 & $5,9 \%$ & Tidak Menarik & 2 & $5,9 \%$ \\
$\begin{array}{l}\text { Menarik } \\
\text { Warna }\end{array}$ & 32 & $94,1 \%$ & Menarik & 32 & $94,1 \%$ \\
Tidak Menarik & & & Warna & & \\
Menarik & 0 & $0 \%$ & Tidak Menarik & 2 & $5,9 \%$ \\
\hline
\end{tabular}

Tabel 3.

Perbedaan persepsi cita rasa lauk nabati sebelum dan sesudah modifikasi menu

\begin{tabular}{llll|llll}
\hline & $\begin{array}{l}\text { Rata-rata } \\
\text { Tempe } \\
\text { Balado }\end{array}$ & $\begin{array}{l}\text { Rata-rata } \\
\text { Tumis Tempe } \\
\text { Cabai Hijau }\end{array}$ & $\boldsymbol{p}$ & & $\begin{array}{l}\text { Rata-rata } \\
\text { Tahu Goreng }\end{array}$ & $\begin{array}{l}\text { Rata-rata } \\
\text { Tsi }\end{array}$ & \\
\hline Rasa & 1,58 & 2,00 & 0,000 & Rasa & 1,41 & 2,00 & 0,000 \\
Aroma & 1,52 & 1,97 & 0,000 & Aroma & 1,26 & 2,00 & 0,000 \\
Tekstur & 1,67 & 1,82 & 0,197 & Tekstur & 1,82 & 1,88 & 0,527 \\
Bentuk & 1,79 & 1,94 & 0,96 & Bentuk & 1,82 & 1,94 & 0,157 \\
Warna & 1,70 & 2,00 & 0,002 & Warna & 1,50 & 1,94 & 0,001 \\
\hline
\end{tabular}

Tabel 4.

Perbedaan asupan energi dan zat gizi makro sebelum dan sesudah modifikasi menu

\begin{tabular}{|c|c|c|c|c|c|}
\hline Variabel & Mean & SD & $\Delta$ Mean & $p$-Value & $\mathbf{n}$ \\
\hline \multirow{2}{*}{$\begin{array}{l}\text { Asupan Energi Sebelum - Asupan } \\
\text { Energi Sesudah }\end{array}$} & 1113,4 & 328,5 & 356,2 & 0,000 & 34 \\
\hline & 1469,6 & 159,7 & & & \\
\hline \multirow{2}{*}{$\begin{array}{l}\text { Asupan Karbohidrat Sebelum - } \\
\text { Asupan Karbohidrat Sesudah }\end{array}$} & 123,8 & 35,76 & 65,6 & 0,000 & 34 \\
\hline & 189,4 & 30,42 & & & \\
\hline \multirow{2}{*}{$\begin{array}{l}\text { Asupan Protein Sebelum - Asupan } \\
\text { Protein Sesudah }\end{array}$} & 33,6 & 9,80 & 7,5 & 0,001 & 34 \\
\hline & 41,1 & 6,30 & & & \\
\hline \multirow{2}{*}{$\begin{array}{l}\text { Asupan Lemak Sebelum - Asupan } \\
\text { Lemak Sesudah }\end{array}$} & 54,1 & 20,89 & 9,6 & 0,012 & 34 \\
\hline & 63,7 & 17,23 & & & \\
\hline
\end{tabular}




\section{DISKUSI}

Terdapat perbedaan persepsi cita rasa pada aspek rasa, aroma, dan warna sebelum dan sesudah lauk nabati dilakukan modifikasi. Adanya perbedaan ini menunjukkan persepsi subjek terhadap tempe balado sesudah modifikasi resep dari segi rasa sudah baik. Hal ini dilihat dari tumis tempe cabai hijau yang sudah digoreng setengah matang lalu ditumis kembali bersamaan dengan bumbu, udang rebon dan pemberian garam serta gula diperhatikan untuk menghasilkan rasa yang enak. Pada lauk nabati tahu, rasa tahu goreng isi sesudah pengembangan resep lebih terasa bumbu dan penambahan seperti garam dan gula yang digunakan secukupnya agar rasanya tidak hambar seperti tahu goreng sebelum dimodifikasi.

Dari segi aroma, pada lauk nabati tempe sudah baik. Hal ini disebabkan pada proses pembuatan tumis tempe cabai hijau ini ditambahkan udang rebon, bawang putih dan bawang merah, serta ditambahkan cabai hijau sehingga aromanya menggugah selera. Dilihat dari masakan tahu goreng yang dimodifikasi menjadi tahu goreng isi ditambahkan isian pada tahu yang sebelumnya isian tersebut ditumis dan ditambahkan bumbu. Bumbu adalah bahan yang ditambahkan pada makanan untuk mendapatkan rasa makanan yang enak dan sama setiap kali pemasakan. Dengan demikian, pemberian bumbu dan rempah-rempah dalam makanan tetaplah harus diperhatikan. Hal ini penting untuk menciptakan aroma yang enak dan disukai oleh subjek (Aula, 2011) bahwa timbulnya aroma makanan disebabkan oleh terbentuknya suatu senyawa yang mudah menguap.

Pada aspek warna, terdapat perbedaan pada hidangan lauk nabati tempe dan tahu. Adanya perbedaan ini menunjukkan persepsi subjek terhadap lauk nabati sesudah modifikasi resep dari segi warna sudah baik. Hal ini dilihat dari resep standar tempe balado dan tahu goreng yang dikembangkan menjadi tumis tempe cabai hijau dan tahu goreng isi menggunakan bumbu yang berbeda dan menghasilkan warna tempe dan tahu sesudah pengembangan resep lebih menarik. Untuk tahu goreng isi yang sudah dimodifikasi terlihat lebih menarik karena warna yang coklat dan dibaluri oleh tepung, dan terdapat isi wortel dan hijau yang membuat tahu goreng isi ini lebih menarik. Menurut (Meriska, 2004) kombinasi warna merupakan faktor yang memengaruhi indera penglihatan, oleh karena itu tenaga pengolah makanan harus benarbenar mengerti adanya perbedaan warna sebelum dan sesudah diolah.

Adanya perbedaan pada persepsi citarasa sebelum dan sesudah dimodifikasi menu makanan yang dinilai dari penampilan dan rasa karena adanya variasi bahan makanan dan variasi bumbu yang dipakai. Berdasarkan penelitian di SDIB AnNissa, dapat disimpulkan bahwa ada perbedaan daya terima makan siang SDIB An-Nissa dan YPI SD Nasima Kota Semarang $(p<0,05)$. Hal ini 
disebabkan oleh beberapa faktor yaitu rasa makanan dan penampilan makanan dan tekstur makanan yang disajikan. Pada aspek tekstur dan bentuk, tidak terdapat perbedaan, hal ini dikarenakan tekstur tempe dan tahu memang sama dan bentuk tidak divariasikan sehingga tidak menarik.

Pada Panti Asuhan AlIkhwaniyah Tangerang Selatan dengan memodifikasi lauk nabati pada menu makan siang dan malam dapat memengaruhi asupan energi dan zat gizi makro untuk memenuhi kebutuhan sehari-hari dan sebagai salah satu usaha untuk melihat adanya perbedaan asupan zat gizi makro pada anak-anak Panti Asuhan Al-Ikhwaniyah, sehingga dapat dilihat bahwa meningkatnya tingkat kesukaan pada hidangan nabati dapat meningkatkan asupan energi dan zat gizi makro.

Hasil penelitian ini mendukung hasil penelitian yang dilakukan pada remaja putri panti asuhan Darul Khadlonah dan pondok pesantren Baitul Muqodas Pekalongan ini menunjukkan bahwa asupan energi pada remaja putri panti asuhan Darul Khadlonah dan pondok pesantren Baitul Muqodas terdapat perbedaan yang bermakna $\quad(p<0,00)$. Pada penelitian sebelumnya yang dilakukan oleh Mira (2017) di Pondok Pesantren Al-Muhsin Lampung bahwa terdapat perbedaan yang bermakna pada asupan zat gizi makro sebelum dan sesudah menu makanan dimodifikasi, hal ini melihat jumlah makanan yang dapat dikonsumsi oleh sesorang sehingga dapat menggambarkan asupan zat gizi seseorang berarti terdapat perbedaan yang signifikan antara asupan energi sebelum modifikasi lauk nabati dengan asupan energi sesudah modifikasi.

Hasil penelitian ini sejalan juga dengan hasil penelitian Yanti (2017) yang menyatakan bahwa ada pengaruh modifikasi resep lauk nabati tempe terhadap sisa makanan pasien yang mendapat makanan lunak TKTP. Setelah dilakukan modifikasi, terjadi penurunan sisa makanan. Rata-rata sisa makanan lauk nabati tempe tanpa modifikasi $55,45 \%$ dan dengan modifikasi 39,59\%.

\section{SIMPULAN}

Terdapat perbedaan antara persepsi citarasa lauk nabati tempe sebelum dan sesudah dimodifikasi dengan persen rata-rata tempe balado $65,86 \%$ dan sesudah dimodifikasi tumis tempe cabai hijau 94,72\%. Terdapat perbedaan antara persepsi citarasa lauk nabati tahu sebelum dan sesudah dimodifikasi dengan persen rata-rata tahu goreng $56,6 \%$ dan sesudah dimodifikasi tahu goreng isi $95,28 \%$. Terdapat perbedaan antara asupan energi dan zat gizi makro sebelum dan sesudah dimodifikasi dengan perbedaan selisih ( $\Delta$ Mean) 356,2 kkal dari asupan energi sebelum dan sesudah dimodifikasi, perbedaan selisih (AMean) 65,6 g asupan karbohidrat sebelum dan sesudah dimodifikasi, perbedaan selisih ( $\Delta$ Mean) 7,5 $\mathrm{g}$ asupan protein sebelum dan sesudah dimodifikasi dan 
perbedaan selisih ( $\Delta$ Mean) 9,6 $\mathrm{g}$ asupan lemak sebelum dimodifikasi.

\section{DAFTAR RUJUKAN}

Amelia, AR., Syam, A., \& Fatimah, S. (2013). Hubungan Asupan Energi dan Zat Gizi dengan Status Gizi Santri Putri Yayasan Pondok Pesantren Hidayatullah Makasar Sulawesi Selatan Tahun 2013. Skripsi. Fakultas Kesehatan Masyarakat Universitas Hasanuddin. Makasar.

Anzarkusuma, IS., Mulyani, EY., Jus'at, I., Angkasa, D. (2014). Status gizi berdasarkan pola makan anak Sekolah Dasar di Kecamatan Rajeg Tangerang. Indonesian Journal of Human Nutrition, 1(2): 135-148.

Aula, LE. (2011). Faktor-faktor yang Berhubungan dengan Terjadinya Sisa Makanan pada Pasien Rawat Inap di Rumah Sakit Haji Jakarta. Skripsi. Fakultas Kedokteran dan Ilmu Kesehatan. Universitas Islam Negeri Syarif Hidayatullah. Jakarta.

Azza, D., Defiani, F., Mahfuzhoh, Tiwi, M. (2016). Modifikasi Resep Lauk Nabati (Steak Tahu) dan Sayur [(Sambal Cis Pot (Buncis-Potato)] dalam Siklus Menu Kelima di Unit Gizi RSPAD Gatot Soebroto Ditkesad. Laporan Praktik Kerja Lapangan. Poltekkes Tasikmalaya. Cirebon.
Pahlevi, AE. (2012). Determinan Status Gizi pada siswa sekolah dasar. Jurnal Kesehatan Masyarakat, KEMAS $7(2), 122-126$.

Irianto, K. dan Waluyo, K. (2010). Gizi dan Pola Hidup Sehat. Bandung: Yrama Widya.

Khusniyati, E., Sari, AK., dan Ro'ifah, I. (2016). Hubungan pola konsumsi makanan dengan status gizi santri Pondok Pesantren Roudlatul Hidayah Desa Pakis Kecamatan Trowulan Kabupaten Mojokerto. Midwiferia Jurnal Kebidanan, 2(2).

Meriska. (2004). Konsumsi dan Persepsi Pasien Rawat Inap terhadap Makanan serta Faktor-faktor yang Memengaruhi di RSUD Abdul Moelek Lampung. Skripsi. Fakultas Ekologi Manusia IPB. Bogor.

Mira. (2017). Perbedaan Persepsi Cita Rasa dan Asupan Zat Gizi Sebelum dan Sesudah Modifikasi Menu di Pondok Pesantren Al-Muhsin Lampung. Skripsi. Jakarta.

Yanti, DS. (2017). Pengaruh Modifikasi Resep Lauk Nabati Tempe terhadap Sisa Makanan Pasien yang Mendapat Makanan Lunak TKTP di Ruang Rawat Inap RSUP Dr. M. Djamil Padang Tahun 2017. Skripsi. Politeknik Kesehatan, Kemenkes RI, Padang. 